\title{
MINERALIZATION EPISODES AND THEIR CONCENTRATION SITES IN A TYPICAL BRITISH COAL
}

\author{
G. O. ASUEN, F. A. LUCAS AND O. A. ILEGIEUNO \\ (Received 4 March, 2009; Revision Accepted 22 May, 2009)
}

\begin{abstract}
Twenty four (24) coal samples from the eight (8) working collieries of Northumberland coalfield, England, have been studied with the view to analyzing the possible location/concentration of the mineral species in coals. The results of the study showed that their clay mineral suites dominated by kaolinitic types are disseminated products at maceral boundaries, desiccation cracks and at times fissures with no established genetic evidence. The other widespread variety of mineral occurrences, notably calcite, siderite and sometime pyrite in the coal basin and traceable to precipitates in various joints, cleats, cell voids and lumens are associated/formed during epigenetic mineralization episode (post depositional phase), when the macerals have differentiated into their various entities. More importantly, these mineral concentration appears to have been partly or wholly controlled by the semifusinite/fusinite macerals (i.e. particularly those exhibiting "Bogenstruktur") as the preferred traps and/or infills for coals. With the exception of the nodular pyrite that is said to be linked to both vitrinitic and sometimes liptinitic macerals and are traceable to syngenetic mineralization episodes, the euhedral type pyrite demonstrates a complete unique behaviour by their infill of semifusinite/fusinite macerals which suggests the timing to be of post-depositional phase.
\end{abstract}

KEYWORDS: British coals, Mineral species, Concentration sites

\section{INTRODUCTION}

The available information on the occurrence, identity and distribution of mineral species with particular references to British coals was prepared by Watt (1968). On the other hand, a comparative little attention has been given to mineral species and their concentration sites because such an assessment of coals can be said to be purely for scientific reasons. However the essential nature of the mineral species associated with these coals have been the subject of continuing discussion and investigation (Nicholls and Loring 1962, Edeh et. al. 1963, Spears 1964, Price et. al. 1969, Taylor and Spears 1970, Spears 1971, Spears et. al. 1971, Pearson 1979). From the scientific standpoint, less than complete account have been given to the studies between coals and their inorganic sites as another approach at offering a plausible explanation of the characteristic properties of coals.

The unique historical events associated with mineral species during the stages of coal forming process have in no way been solved or diminished, instead the depositional mineralization episodes have become more significant at enhancing the increase utilization for coals. For example, the inorganic constitution that seems to be less complex (because it is easily separated and/or differentiated from their organic components) have been found to be of post-depositional phase. The compelling evidence for this, suggests that the inorganic emplacement, mobilization, precipitation or as infillings in voids, fissures, cracks, cavities etc (extrinsic or free) are also associated to the maceral species. The rather inseparable, fixed, intrinsic, intimately interwoven and/or chemically bound to coal components are developed in the diagenetic phase of the coal forming processes. This two classes of inorganic input often serve to characterize the coals. The former appears to be easily distinguishable in practice being an important tool in aiding and distinguishing coals on the basis of their quality and/or purity (i.e. control the coal value as an energy source).

Therefore recording the mineral species and their precise sites of concentration can vary enormously and to a great extent determine their behaviour, abundance and distribution in coals. The perographic alternative seeks to provide more detailed explanation of the role of these inorganic inputs.

\section{SAMPLING AND ANALYTICAL TECHNIQUES}

Carboniferous coal samples collected from Northumberland coalfield were accessible from the existing eight (8) collieries (Fig. 1). These samples were randomly taken from top to bottom in the area where good exposures existed throughout the entire collieries. From each colliery, three (3) samples were identified and collected at specified intervals. A total of twenty-four (24) representatives samples selected from the collieries/area were subjected to petrographic sample preparation similar to the method adopted in Asuen and Onyeobi (2006).

Further investigation employed the reflected light/oil immersion and the scanning electron microscopic techniques of coal petrology to identify and locate the relationship of the mineral species within the macerals (Asuen 1984). The advantages of these techniques show that the qualitative information of some major mineral species which include calcite, pyrite, quartz and occasionally siderite can be observed/studied with the slightest difficulty. The other coal forming minerals which are so widely disseminated and very fine (i.e. clay minerals) and are beyond the limit of resolution of the conventional microscope (limit of 
detection restricted to abundance $>1000 \mathrm{ppm}$ ) were further analyzed at submicron level with the scanning electron microscopy (SEM). The individual elements distribution photomicrograph as well as the superimposed digital maps produced blended images that reflect the mineral phases. Consequently, this techniques has been able to provide qualitative information for only few major elements, namely, Silicon
(Si), Aluminium (Al), Potassium (K), Iron (Fe), Sulpur (S) and Calcium (Ca). Furthermore, the contrasting colour pattern also relates to the level of intensity (i.e. an indication of relative abundance) of the elements present. For example, bright colour indicates higher concentration while dull colour shows a low level concentration of the elements analyzed.

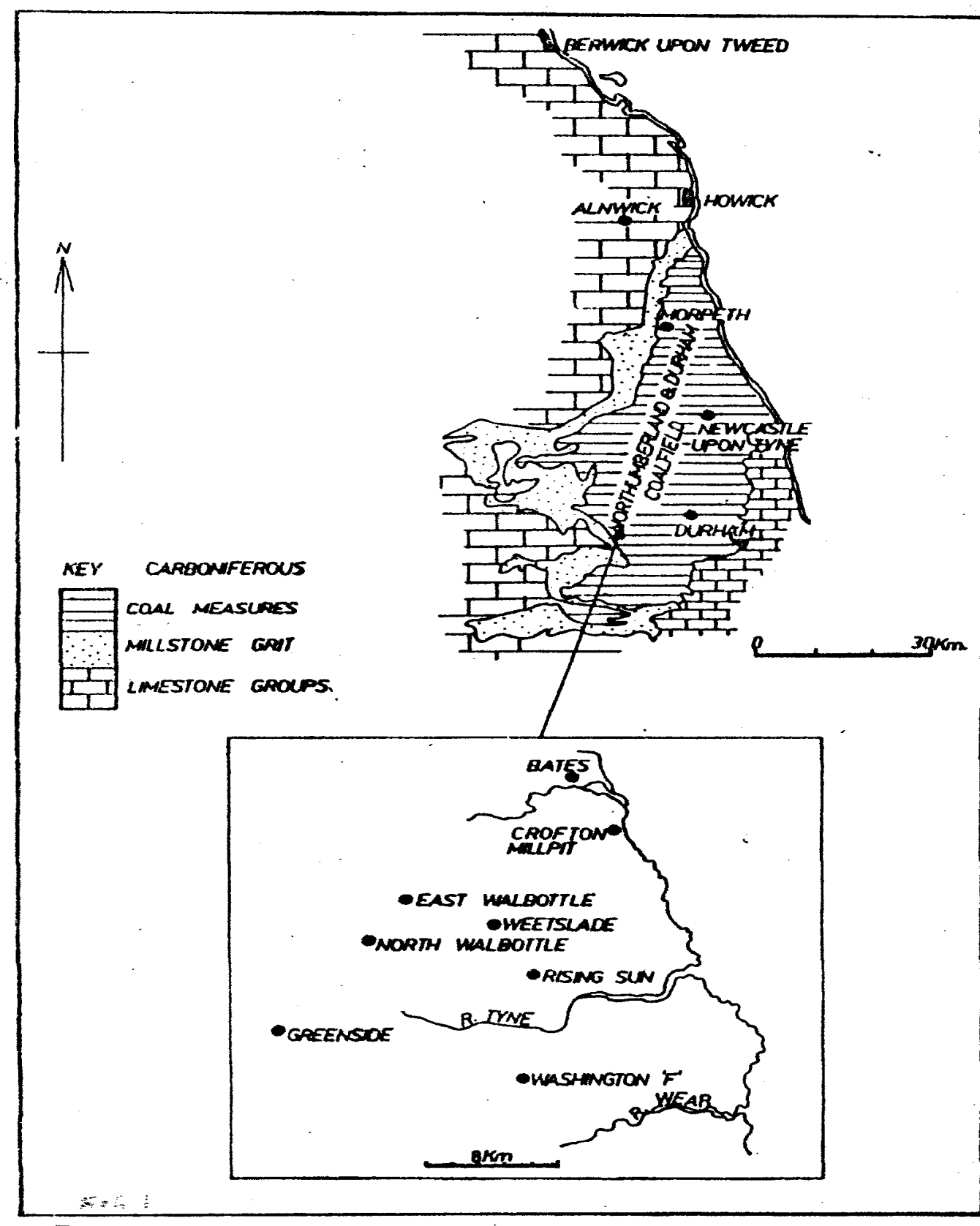

Fig 1: Generalized location/distribution map of the studied collieries in Northumberland, England.

\section{DISCUSSION OF RESULTS}

\section{PYRITE}

Microscopic identification of pyrites in coal is straightforward because of its characteristics high reflectance and golden yellow colour. It differs from the other disulphide mineral (e.g. marcasite) because of its isotropic character. Although an isolated case of marcasite has been shown for the Halifax Hard Bed coal of Northern England (Love et al., 1983), marcasite is generally rare in British coals (Gluskoter and Hopkins, 1970).

The frequently encountered forms of pyrite in the majority of studied or polished blocks cut perpendicular to the bedding are nodular (i.e. spherules) and euhedral forms. The spherule-type pyrites are generally pronounced in vitrinitic and liptinitic macerals. The usual form and association of pyrite spherules with 
coal macerals appear to occur in distinctive ovoid forms (Figs. 2 and 3). The way in which the distinctive nodular pyrite occurs is suggestive of authigenic origins (Balme, 1956). This nodular type owes its origin to the biogenically reduced sulphur that reacts rapidly with available iron to form pyrite. It undoubtedly forms early in the diagenetic stage of coal (i.e. peat stage or precompaction stage). On the other hand, the euhedral forms, which represents the second type of pyrite appears to be dominant also in these coals. It is readily distinguishable by its characteristic crystal shape i.e. triangular, square, octahedron etc. with the unique sharp crystal boundaries (Fig. 4). This form is undoubtedly of secondary origin and the shapes may be attributed to a significant degree to later crystallization or recrystallization after the pyritising episode or it may represent a much slower terminal rate of precipitation as proposed by Coleman and Curtis (1983). Richards (1969) also suggested that the mechanism of their formation is been conditioned by the activity of sulphatereducing micro-organisms but the timing is definitely in the second phase of coalification. Therefore, this pyrite is epigenetic and is usually concentrated as aggregates of crystals infilling in the existing cleats, fissures and/or replacing collapse cell walls of inertinite macerals (See Figs. 4, 5, and 6). The mineralization episode is definitely after the macerals have been completely differentiated and segregated.

Further examination of the nodular (i.e. spherule) pyrite in these coals by SEM reveals the internal structure of framboids. All contain large numbers of sperules. Although the elements iron and sulphur are expected as shown by the digital map (see Fig. 8), the same field of view scanned for the presence of Aluminosilicate (i.e. Aluminium and silicon) was substantiated. This result indicate fairly close relationship between the aluminosilicate and pyrite in the coal studied (Fig. 9). This findings is similar to the work in which a clay fractions with pyrite interstices has been documented (Scheihing et al., 1978). Vallentyne (1963) also noted 0.13 percent $\mathrm{Si}$ in a purified sample of recent spherulitic pyrite. Elverhфi (1977) recorded a clay matrix within some Jurassic frameboids from the northwestern part of the Barents sea. It seems therefore likely that crystallization of pyrite and the formation of koalinite in the Northumberland coals may have occurred at different times.

In considering the euhedral pyrite-forming elemental distribution in the maceral, this pyrite has been established to be closely associated and concentrated also in the fusinite and semifusinite, possible in the 'Bogenstruktur' (Fig. 6) while in the vitrinite fraction, these pyrite seem to be either completely lacking or present in low concentrations. These association with the vitrinite macerals, probably show a relationship indicative of disseminated pyrite in cracks and fissures (Fig. 7).

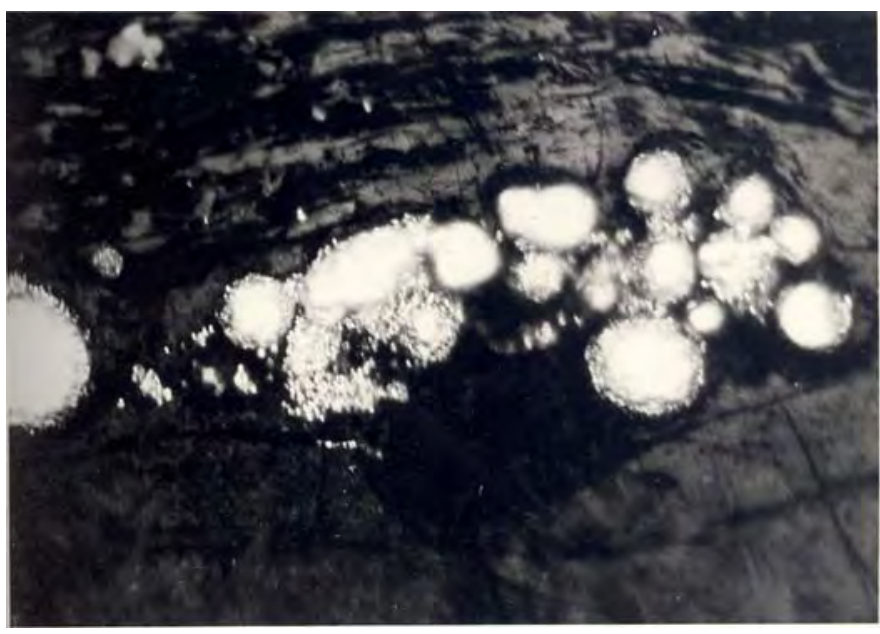

Fig. 2 Pyrite-spherule in Vitrinitic material of coal. (Reflected/oil immersion x 958)

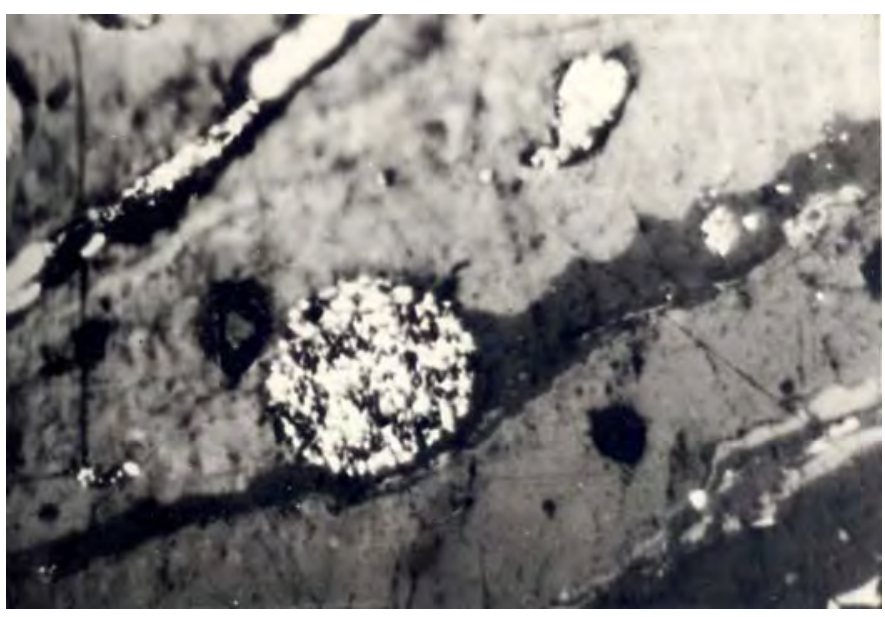

Figure 3: Vitrinite with inclusion of pyrite spherules (Reflected/oil immersion x 958)

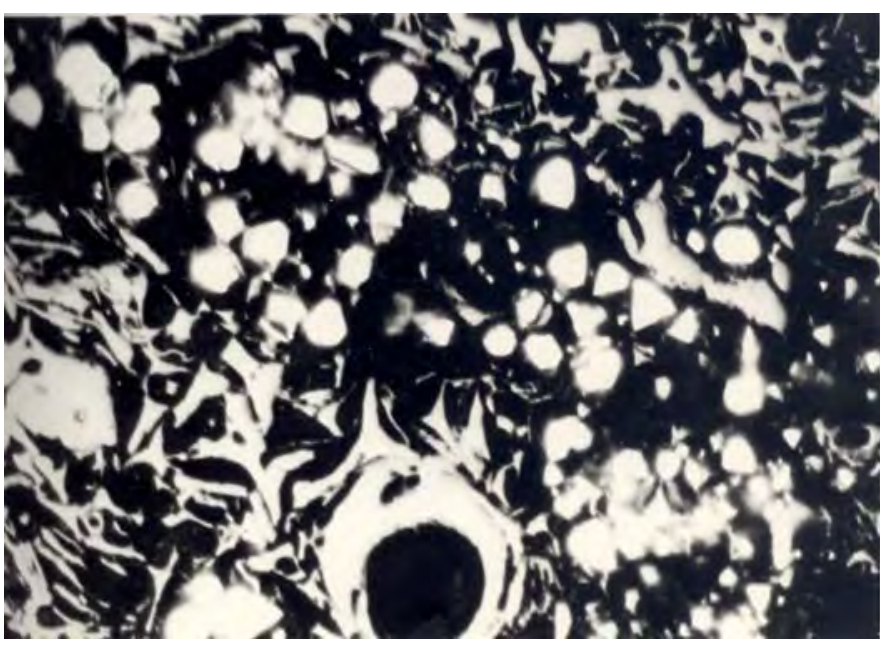

Figure 4: Euhedral pyrite filling the collapsed "Bogen struktur" semifusinite/fusinite. (Reflected/oil immersion $\mathrm{x}$ 958) 


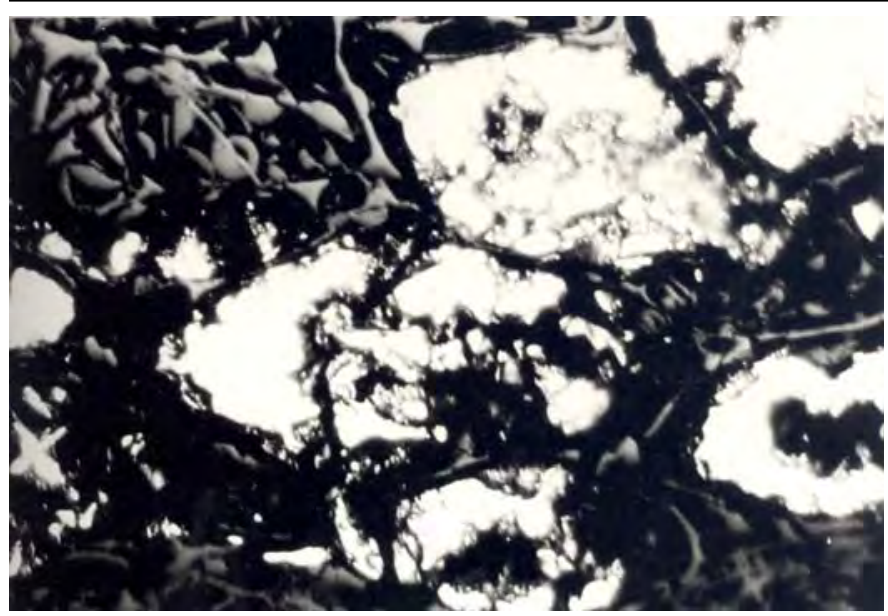

Figure 5: Pyrite filling the cell lumen of very low-reflecting fusinite (Reflected/oil immersion x 958)

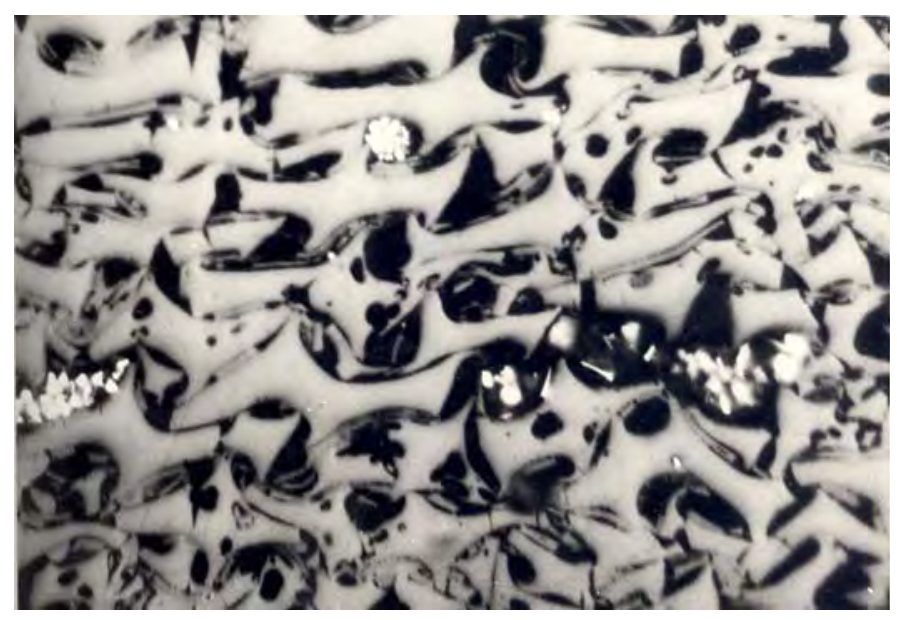

Figure 6: Occasional Euhedral crystal of pyrite in fusinite cell lumen (Reflected/oil immersion $x$ 958)

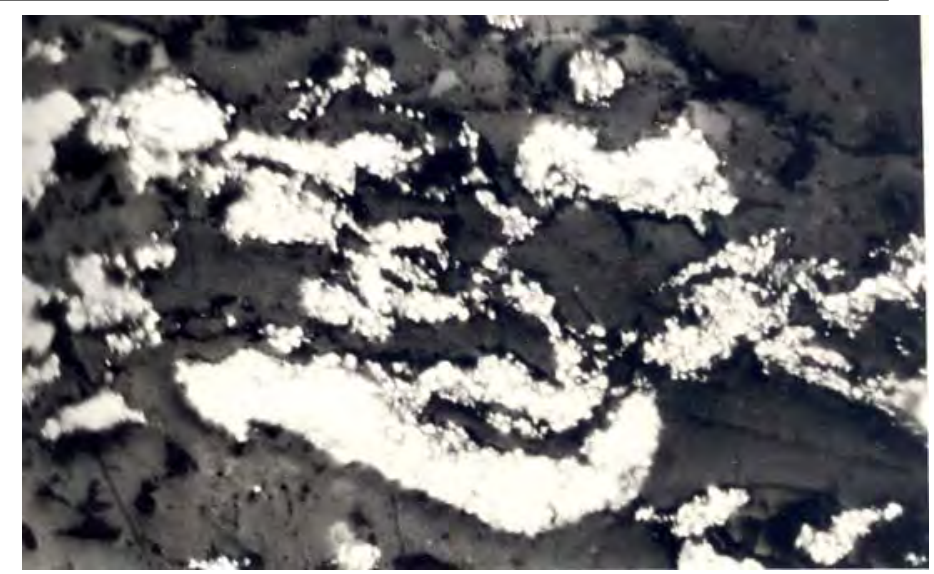

Figure 7: Pyrite filling the dessication cracks of vitrinite (Reflected/oil immersion x 958) 


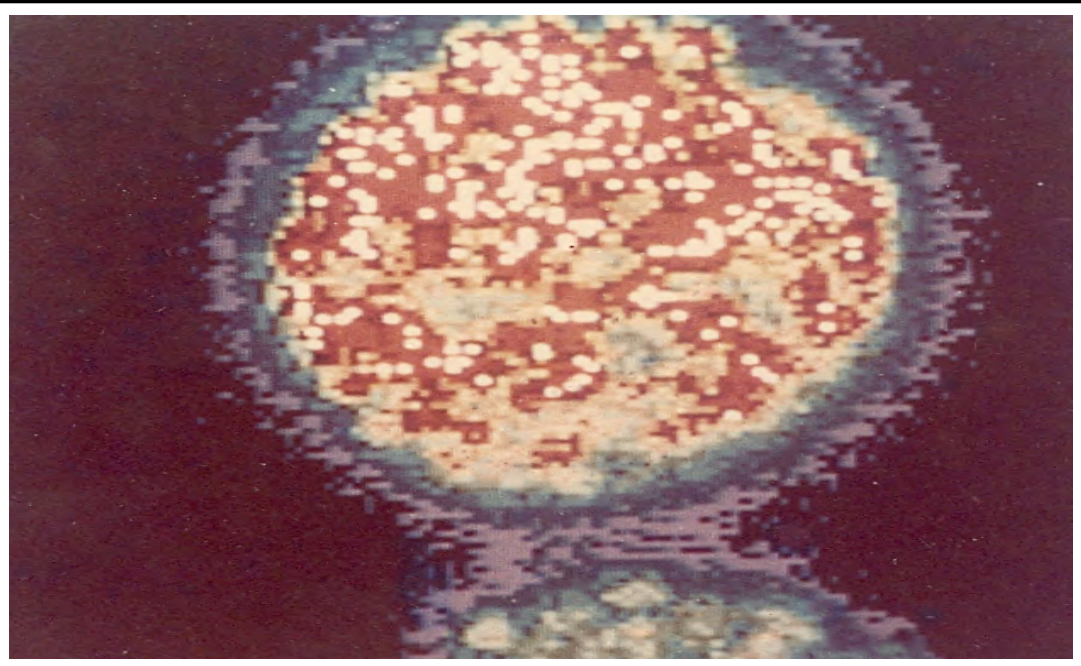

A. Fe-distribution (x 4300)

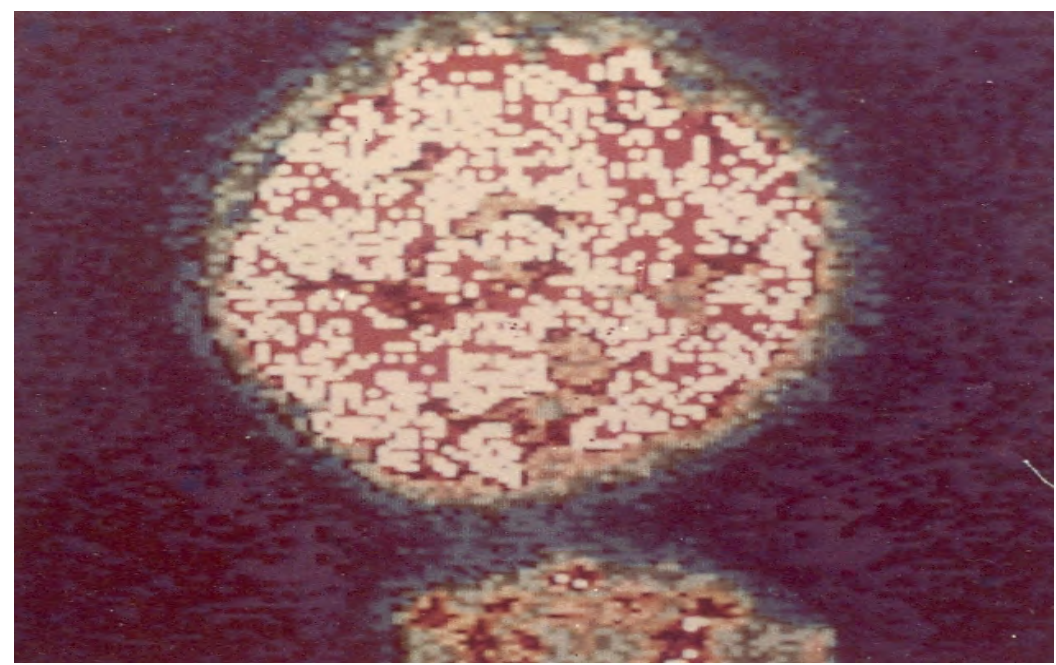

B. S-distribution (x 4300)

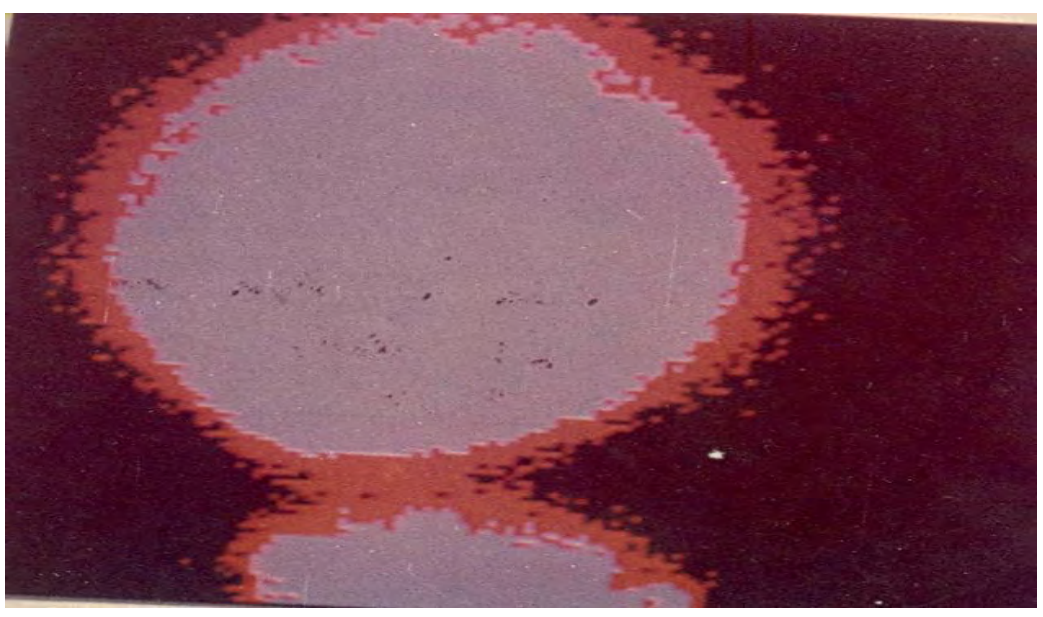

C. Fe/S distribution $(x 4300)$ (Fe-blue and $\mathrm{S}$ - red)

Figure 8: SEM-Digital micrograph of Pyrite frambiod 


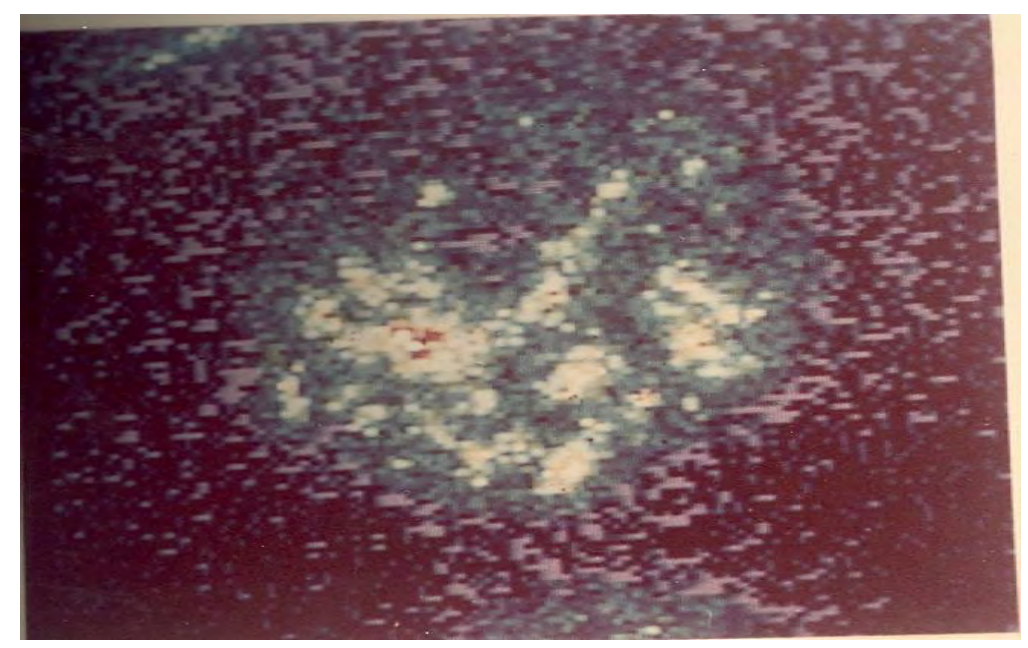

A. Al distribution (x 4300)

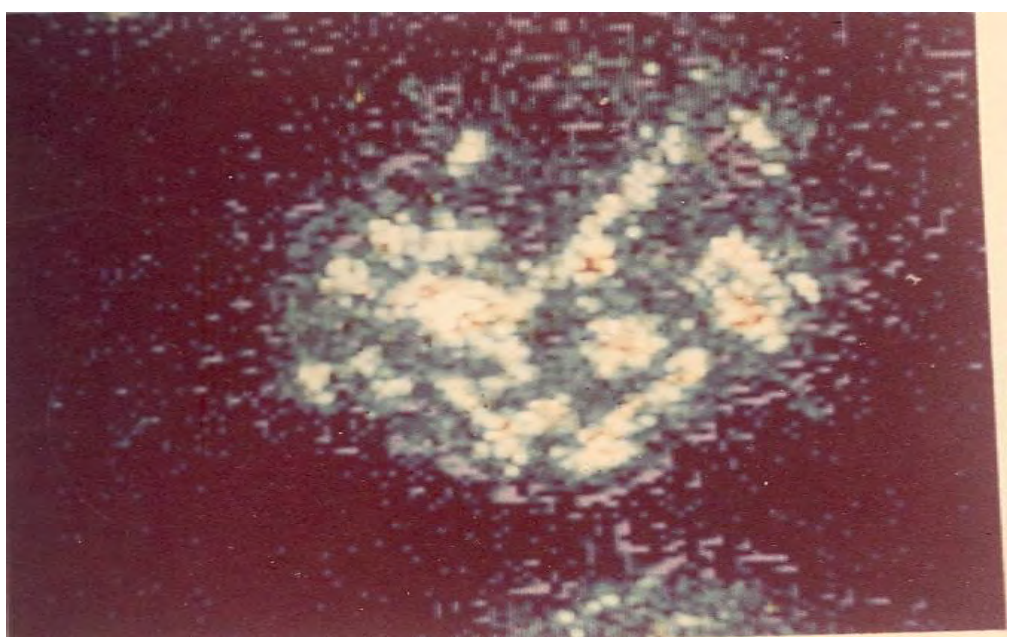

B. Si distribution (x 4300)

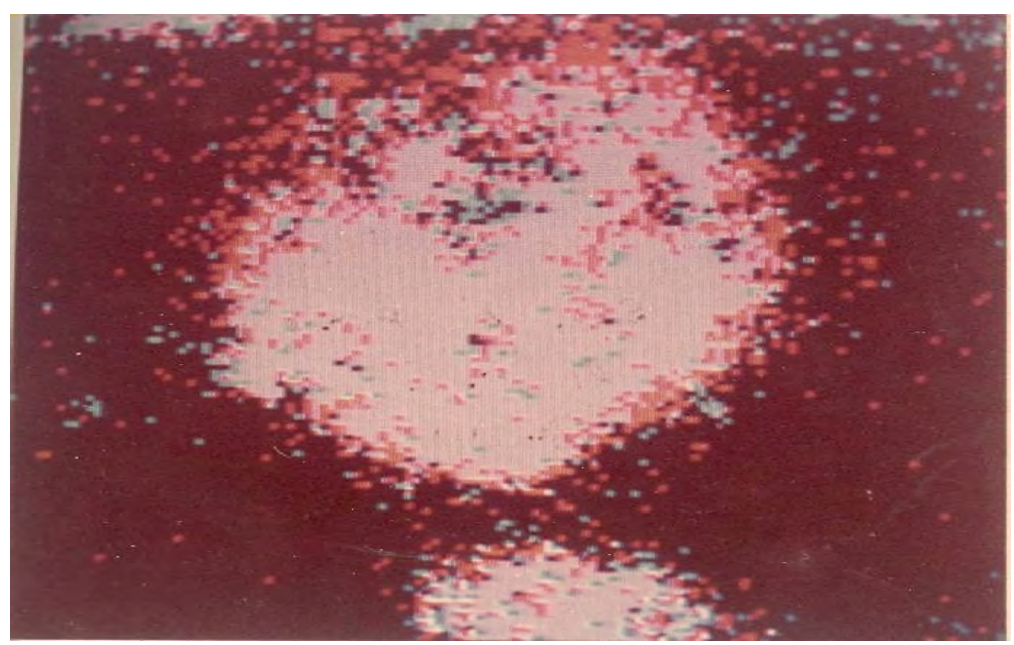

C. Al/Si distribution (x 4300)

(Al-red and Si-blue)

Figure 9: SEM-Digital micrograph of Aluminosilicate

\section{CARBONATE MINERALS}

This group of minerals viz., ankerite, dolomite, calcite and siderite, exhibit significant characteristics, all of which are important in their identification. From the microscopic evidence, however, the latter two minerals namely calcite and siderite were the most easily observed in these coals.

Under reflected light oil immersion objectives, calcite is translucent, sometimes with a brownish cast and shows interference reflections on rotation of the microscope stage. This character makes it a readily 
identifiable mineral. Calcite occurs commonly in the coals studied, usually infilling cells lumens in fusinite and semifusinite (Figs. 10 and 11). Other common occurrences which are in cleats, joints, descication cracks, as well as lenses, bands and/or concretions were retricted to vitrinites and sporinites (Fig 12). Although calcite is associated with all maceral groups, the mineralisation episode is notable for the infilling of available fissures and lumens, an association said to be related to a post depositional activity. The occurrences of this calcite are typical of those coals which have been described as epigenetic (Nelson, 1953; Marshall and Tompkins 1964) and whose origin may well be connected with precipitation and/or recrystallisation conditioned by suitable environmental conditions.

The SEM distribution pattern for calcite has also been shown to be linked with inertinite macerals, this being one of the maceral groups that usually retains this mineral. The same field of view was scanned for phosphorous, but if present, it lay below the limit of instrumental detection. As a result, an apatite origin in this coals cannot be suggested here. Calcite association with inertnite is often not syngenetic but rather linked to post depositional processes of coal formation. (Asuen, 1984).

The siderite which represent another type of carbonate mineral appears to be dominant in these coals except for the few samples where their presence could not be documented. When the siderite is found, it is readily distinguishable by its characteristic shapes. These minerals are undoubtedly of secondary origin because to a great extent are associated with mainly semifusinite and fusinite macerals (Fig. 13).

\section{CLAY MINERALS}

The relationship of clay minerals suites to the coals macerals has been made possible by SEM study. The digital photomicrographs clearly show the aluminosilicate and/or potassium aluminium silicate minerals (i.e. as superimposed images of the forming elements). X-ray diffraction analysis has also confirmed the presence of kaolinite and illite (Asuen, 1987). Apart from the fact that clay minerals are highly abundant, their associations are restricted to a particular maceral group; notably the semifusinite. The lack of clay mineral presence recorded with the vitrinite and liptinite macerals may well be for genetic reasons. Evidence of liptinitic maceral associations (i.e. Sporinite) investigated for aluminium, silicon, potassium, show an interesting tendency with the superimposed images indicating clay minerals. They are however distributed around the megaspores and within the remnants of its internal cavity (Fig. 14). The mode of such an occurrence is a possible indication of the absence of genetic linkage between clay minerals and coal sporinite. In short, the association of this mineral appears to follow a similar pattern with the digital map for calcite (i.e. non-genetic association).

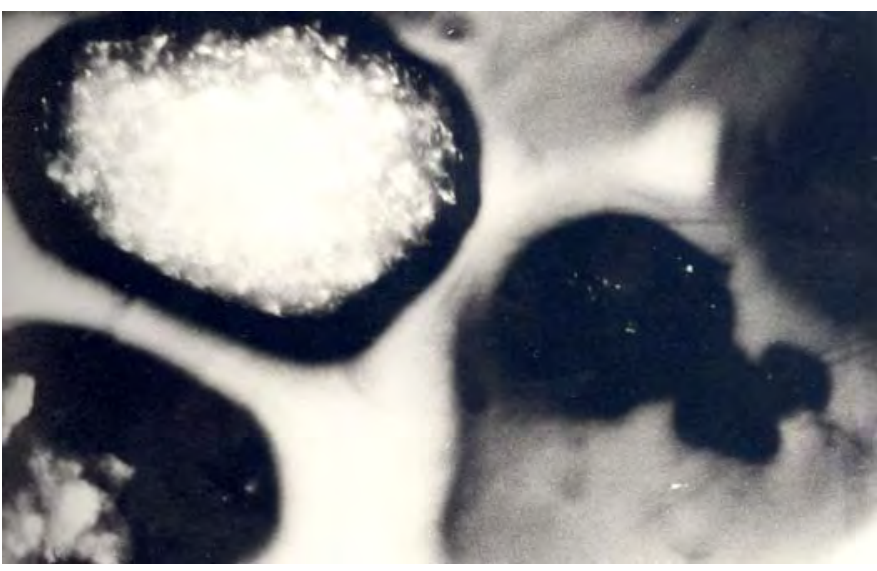

Figure 10: Typical calcite minerals infilling (Bogenstruktur) fusinite (Reflected/oil immersion x 958)

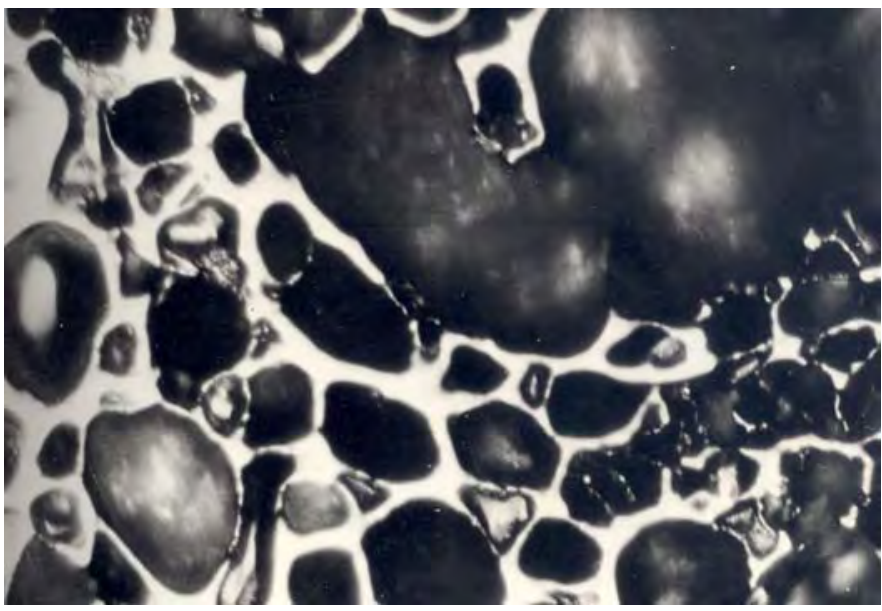

Figure 11: Calcite Minerals infilling the semifusinitel fusinite (Reflected/oil immersion x 958)

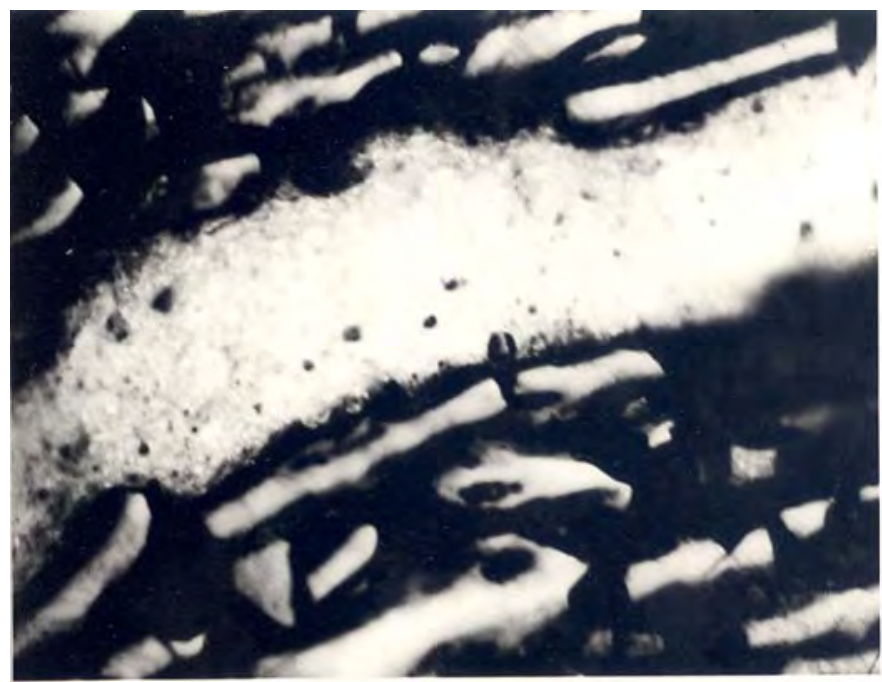

Figure 12: Massive calcite surrounded by ruptured fusinite (Reflected/oil immersion x 958) 


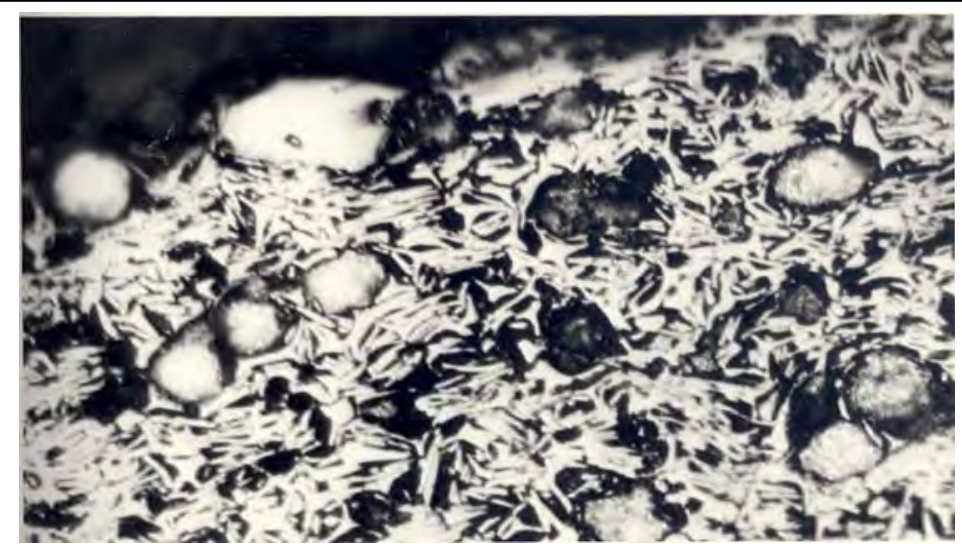

Figure 13: Siderite concretrons in fusinite Lumen (Reflected/oil immersion x 958)

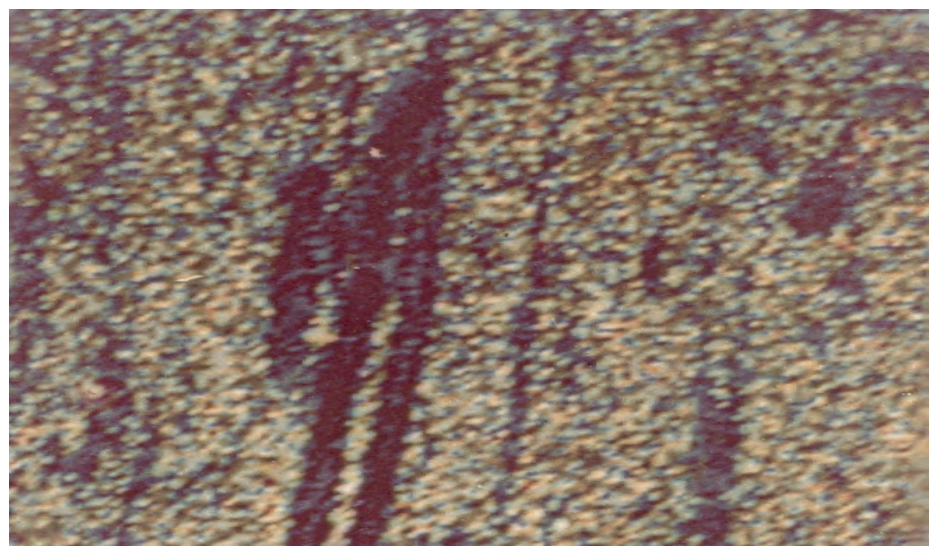

A. Al distribution (x 650)

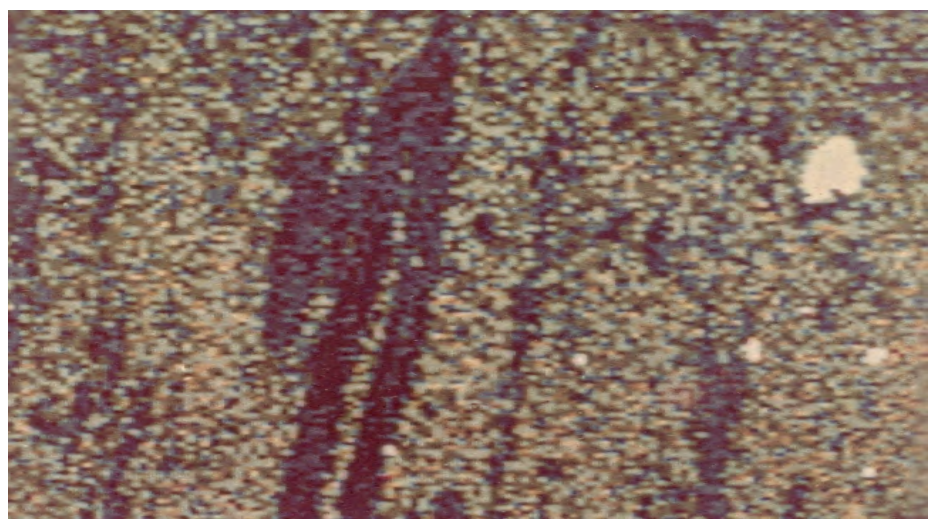

B. Si distribution (x 650)

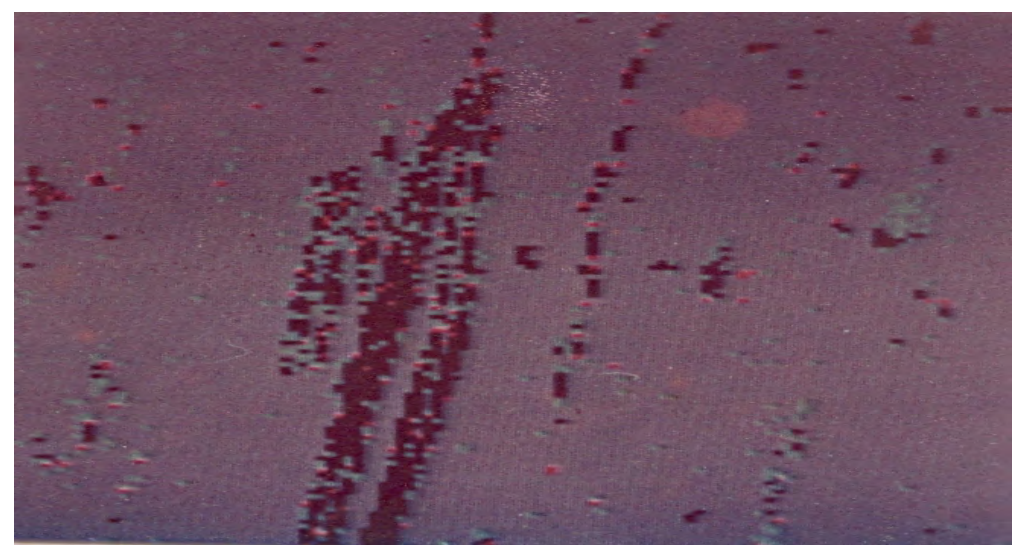

C. Al/Si distribution $(x 650)$

(AI - re and Si - blue)

Figure 14: Siderite concretrons in fusinite Lumen (Reflected/oil immersion x 958) 
CONCLUSIONS

Based on the digital photomicrographs, the commonly occurring minerals show little or no differences in the several coals studied. The difficulties involved in attempting to use the mineral species to differentiate between coals may be due to the concentration of the minor minerals whose detection and illustration have been impracticable. However, the following conclusions can be drawn.

1. The clay minerals, which are the major mineral group found in these coals occur both widely dispersed in the coal matrix and sometimes developed at boundaries and fissures. There is no indication of these minerals being genetically associated with the macerals groups particularly the vitrinite and liptinite macerals.

2. Calcite, siderite, and sometimes pyrite, often infill the cell lumens of the inertinite macerals group, as well as occurring in various joints, dessication cracks of coals. The minerals have been found to be associated with all the macerals groups in the coals. They may have represented inorganic matter that either migrated into the basin or formed authigenically by reconstitution of their constituent elements.

3. Virtually all the spherule-type pyrites in these coals are associatetd with vitrinitic and sometimes with liptinitic macerals. This form of sulphur is often intimately associated with the coal material (formed during the diagenetic stage of coalification).

4. The semifusinite/fusinite macerals (i.e. particularly those exhibiting 'Bogenstruktur') serve as the preferred sites for most variety of minerals matter. On the other hand, the vitrinite and sporinite macerals are low in terms of mineral matter association in these coals.

\section{REFERENCES}

Asuen, G. O., 1984. Major and minor elements in some British Carboniferous coals and their relationship to coal type. Ph.D These. Univ. Newscastle upon Tyne, 305p.

Asuen, G. O., 1987. Mineralogical characteristics of two coal types from different paleoenvironments. Nig. Jour. Mining and Geol., 23, No 1and 2, 81.

Asuen, G. O. and Onyeobi, T. U. S., 2006. Optical evaluation of some Carboniferous coal types from N. E. England and Scottish Fife. Global Jour. Geol. Sci. 4(2): 157

Balme, B. E., 1956. Inorganic sulphur in some Australian coals. Jour. Inst. Fuel, vol. Xxix, 180, 21.

Eden, R. A., Elliot, R. W., Elliot, R. E. and Young B. R., 1963. Tonstein bands in the coalfield of the East Midlands. Geol. Mag., 100, 47.
Elverhoi, A., 1977. Origin of framboidal pyrite in clayey Holocene sediment and in Jurassie black shale in the Northwestern part of the Barents sea. Sedimentology, vol. 24, 501.

Gluskoter, H. J. and Hopkins, N. E., 1970. Distribution of Sulphur in Illinois coals. In: Depositional environment in parts of the Carbondale formation Western and Northern Illinois. (eds W. H. Smith et al.), Illinois state Geol. Surv. Guidebock series Nr. 8, 89.

Love, L. G., Coleman, M. L., and Curtis, C. D., 1983. diagenetic pyrite formation and sulphur isotope fractionation associated with a Westphalian marine incursion, Northern England. Transc. Royal Soc. Edinburgh: earth Science, 74, 165.

Marshall, C. E. and Tompkin, D. K., 1964. Mineral matter in Permian coal seams. In: Symposium on the inorganic constitution of fuel, origin, influence and control,. Univ. of Melbourne, 57.

Nelson, J. B., 1953. Assessment of the Mineral species associated with coal. Brit. Coal Util. Res. Assoc. Bull., vol. 17, Nr. 2, 41.

Nicholls, G. D. and Loring, D. H., 1962. The geochemistry of some British Carboniferous Sediments. Geochimica et. Cosmochima Acta., vol. 26, 181.

Pearson, M. J., 1979. Geochemistry of the Hepworth Carboniferous sediment sequence and origin of the diagenetic iron minerals and concretions. Geochimica et. Cosmochimma Acta., vol. 43, 927.

Price, V., Jr., Stratton, L. P. and Leitner, C., 1969. The role of sulphide producing bacteria in the control of trace metal concentration in ground water. Geol. Soc. Amer., vol. 64, Nr. 7, 832

Richards, D. T., 1969. The microbiological formation of iron sulphide. Stockholm contr. Geol., vol. 20, 49.

Scheihing, M. H., Gluskoter, H. J., and Finkelman, R. B., 1978. Intertitial network of koalinite with pyrite framboid in the Meig Creek coal of Ohio. Jour. Sed. Petr., vol. 48, 3, 723.

Spears, D. A., 1964. The radioactivity of the Mansfield Marine Band. Yorkshire. Geochimica et. Cosmochima Acta. 28. 673.

Spears, D. A., 1971. The Mineralogy of the Stafford Tonstein. Proc. Yorks. Geol. Soc., 38, 497.

Spears, D. A., Taylor, R. K., and Till, R., 1971. A Mineralogical and geological investigation of a spoil heap at Yorkshire main collery. Q. Jl. Engn. Geol. 3, 239. 
Taylor, R. K., and Spears, D. A., 1970. The breakdown of British coal Measures rock. Int. Jour. Rock Mech. Min. Sci., 17, 481.
Watt, J. D., 1968. The physical and chemical behaviour of the mineral matter in coal under the conditions met in combustion plant: a literature survey, part 1- the occurrence, origin, identity, distribution and estimation of the mineral species in Leatherland, Surrey, England, 121p. 